\begin{tabular}{|l|l|l|}
\hline \multicolumn{2}{|c|}{ PublisherInfo } \\
\hline \hline PublisherName & $:$ & BioMed Central \\
\hline \hline PublisherLocation & $:$ & London \\
\hline \hline PublisherImprintName & $:$ & BioMed Central \\
\hline \hline
\end{tabular}

\title{
2003 Royal Society fellows
}

\begin{tabular}{|l|l|l||}
\hline \multicolumn{2}{|c|}{ ArticleInfo } \\
\hline \hline ArticleID & $:$ & 4776 \\
\hline \hline ArticleDOI & $:$ & $10.1186 /$ gb-spotlight-20030519-01 \\
\hline \hline ArticleCitationID & $:$ & spotlight-20030519-01 \\
\hline \hline ArticleSequenceNumber & $:$ & 128 \\
\hline \hline ArticleCategory & $:$ & Research news \\
\hline ArticleFirstPage & $:$ & 1 \\
\hline \hline ArticleLastPage & $:$ & 3 \\
\hline \hline & & RegistrationDate : 2003-5-19 \\
\hline ArticleHistory & $:$ & OnlineDate \\
\hline \hline ArticleCopyright & $:$ & BioMed Central Ltd2003-5-19 \\
\hline \hline ArticleGrants & $:$ & \\
\hline \hline ArticleContext & $:$ & 130594411 \\
\hline \hline
\end{tabular}




\section{David Bruce}

Email: david@thescientisteurope.com

The UK's Royal Society today announced the election of this year's new fellows. Of the 42, nine are women. Female scientists therefore make up $21 \%$ of the new intake, compared with $3 \%$ seven years ago.

A House of Commons report last year found that the percentage of female fellows broadly reflects the number of women in senior academic posts. In fact, only $4.4 \%$ of the fellowship is now female, whereas women represent $9 \%$ of all professors in UK science and engineering departments.

Lord May of Oxford, president of the Royal Society, said in a press release, "The underrepresentation of women in science, engineering, and technology remains a major problem, but progress is being made."

"It is good to note that women represent $11 \%$ of fellows elected in the last five years... As the pool of women in science increases we will see many more excellent and talented female scientists joining the fellowship's ranks."

The percentage of female scientists among the new fellows mirrors that in the recently elected 2003 US National Academy of Sciences fellows, $25 \%$ of whom are women.

Among the new fellows is Kay Davies, at the MRC Functional Genetics Unit, University of Oxford. Davies has been recognized for her work on the molecular analysis of neuromuscular and neurological disorders, specifically Duchenne muscular dystrophy and spinal muscular atrophy.

Another new fellow, molecular geneticist Elizabeth Robertson from Harvard University, was at the forefront in the development of embryonic stem cells and the "knockout mouse" for research purposes. Her primary focus is the TGF $\beta$ family of growth factors. Fiona Watt, at Cancer Research UK's London Research Institute, works on factors that control the growth and differentiation of the keratinocytes that make up stratified squamous epithelia and that are frequent targets for neoplastic conversion.

Karen Vousden, who became director of the Beatson Laboratories in Glasgow last year, has also been elected. Vousden studies the tumor suppression activity of p53 - how p53 induces apoptosis, how this response is regulated, and how p53 activity is lost in carcinogenesis. Mariann Bienz from the MRC Laboratory of Molecular Biology also studies tumor suppression, examining how Wnt signaling in Drosophila can provide clues to the development of human cancers such as adenomatous polyposis coli (APC).

New fellow Bridget Ogilvie is best known as a former director of the Wellcome Trust (1991-1998). She also chaired the Committee for the Public Understanding of Science until her resignation in June 2002. Ogilvie began her scientific career examining the immunogenicity of acetylcholinesterase secretion by the parasite Nippostrogylus brasiliensis in rats. Another parasitologist to join the Royal Society, Keith Gull at the University of Manchester, has provided important insights into the cell cycle and microtubule cytoskeleton of Trypanosoma brucei - the causative agent of sleeping sickness.

Among the biomedical scientists honored is Stephen O'Rahilly at the University of Cambridge, who investigates type 2 diabetes and obesity. His work focuses on defining novel single-gene disorders in 
severe obesity, exploring abnormalities in the insulin signal transduction pathway, and understanding human adipocyte biology.

Fotis Kafatos, director-general of the European Molecular Biology Laboratory, is among the new foreign members. He developed cDNA cloning technology, was instrumental in the Drosophila genome sequencing programme, and coordinated the Anopheles genome sequencing project.

\section{References}

1. 2003 Royal Society fellows, [http://www.royalsoc.ac.uk/framer.asp?page=/royalsoc/ NewFellows.htm]

2. Gavaghan H: MPs report on UK's Royal Society The Scientist, August 1, 2002., [http://www.thescientist.com/news/20020801/03/]

3. Hitt E: New faces at the National Academy Genome Biol, May 13, 2003., [http://genomebiology.com/researchnews/default.asp?arx_id=gb-spotlight-20030513-02]

4. Kay E. Davies, [http://www.mrcfgu.ox.ac.uk/kedavies.htm]

5. Elizabeth J. Robertson, [http://www.mcb.harvard.edu/Faculty/Robertson.html]

6. Fiona Watt, [http://science.cancerresearchuk.org/research/loc/london/lifch/wattf/]

7. Beatson Laboratories, [http://www.beatson.gla.ac.uk/]

8. Mariann Bienz, [http://www2.mrc-lmb.cam.ac.uk/CB/Bienz_M/]

9. Bridget Ogilvie, [http://www.mja.com.au/public/issues/xmas98/ogilvie/ogibox.html]

10. Gavaghan H: Royal Society called to account The Scientist, June 13, 2002., [http://www.thescientist.com/news/20020613/06/]

11. Keith Gull, [http://www.biomed.man.ac.uk/staff/user.asp?id=410\&item=Research]

12. Steven O'Rahilly, [http://www.clbc.cam.ac.uk/newsite/Insulin/rahilly/steve.htm]

13. Fotis Kafatos, [http://www-db.embl-heidelberg.de:4321/emblGroups/g_85.html] 